Zeszyty Naukowe Szkoły Głównej Gospodarstwa Wiejskiego w Warszawie

Problemy Rolnictwa Światowego tom 18 (XXXIII), zeszyt 1, 2018: 48-57

DOI: 10.22630/PRS.2018.18.1.4

Justyna Herda-Kopańska ${ }^{1}$

Instytut Ekonomiki Rolnictwa i Gospodarki Żywnościowej - Państwowy Instytut

Badawczy w Warszawie

\title{
Pomiar mnożnika w rozwoju rolnictwa
}

\section{Measurement of the Multiplier in the Development of Agriculture}

\begin{abstract}
Synopsis. Celem artykułu było zaprezentowanie przeglądu badań na temat pomiaru mnożnika w rozwoju rolnictwa. $\mathrm{Na}$ początku, na podstawie literatury przedmiotu, przedstawiono kilka wybranych wyników analiz oraz wnioski, jakie z nich wypływają. Następnie szerzej omówiono dwie metody. Pierwsza z nich to macierz rachunkowości społecznej (SAM), dzięki której można obliczyć wartości mnożników dla poszczególnych krajów. Natomiast druga omówiona metoda to model inputoutput (przepływów międzygałęziowych), do której zalicza się model IMPLAN. Metoda ta pozwala oszacować regionalne tabele przepływów międzygałęziowych, obliczyć mnożniki oraz dokonać analizy wpływu przemysłu. Zaprezentowane wyniki badań pozwalają stwierdzić, że w gospodarkach mniejszych, które są bardziej otwarte, wielkość mnożnika jest niższa niż w gospodarkach większych. Można również zauważyć, że wśród badaczy nie ma zgodności co do wielkości mnożników.
\end{abstract}

Słowa kluczowe: pomiar mnożnika, macierz rachunkowości społecznej, model input-output, rozwój rolnictwa

\begin{abstract}
The aim of this article was to present a review of research on measuring the multiplier in agricultural development. Firstly, based on the literature of the subject, several selected results of the analyses and the conclusions that emerge from this research are presented. Two methods are further discussed. The first is a social accounting matrix (SAM), which enables calculating the value of multipliers for each country. The second method discussed is the input-output model, which includes the IMPLAN model. This method allows estimating regional input-output tables, calculating multipliers, and analysing the impact of industry. The presented results indicate that in smaller and more open economies the value of the multiplier is lower than in larger economies. It can also be noted that among researchers there is no agreement concerning the size of the multiplier.
\end{abstract}

Key words: measurement of the multiplier, Social Accounting Matrix, input-output model, development of agriculture

JEL Classification: E62, Q10

\section{Wprowadzenie}

W latach 80. XX wieku zaczęto przeprowadzać badania, w których starano się zmierzyć wielkość mnożników w rozwoju rolnictwa. Artykuł prezentuje przegląd tych badań, ich wyniki oraz wypływające wnioski. Ogólnie mówiąc mnożnik to miara proporcjonalnego wpływu zmiennej egzogennej na zmienną endogeniczną. Do obliczenia jego wartości można zastosować m.in. macierz rachunkowości społecznej (SAM) lub model input-output (przepływów międzygałęziowych). Jednym $\mathrm{z}$ takich modeli

\footnotetext{
${ }^{1}$ mgr inż., ul. Świętokrzyska 20,00-002 Warszawa, e-mail: Justyna.Herda-Kopanska@ierigz.waw.pl,
} https://orcid.org/0000-0003-1351-8338 
przepływów międzygałęziowych jest model IMPLAN, dzięki któremu można oszacować regionalne tabele przepływów międzygałęziowych, obliczyć mnożniki, a także przeprowadzić analizę wpływu przemysłu. Wykorzystując model SAM, Trejos i in. (2004) obliczyli wartości mnożników dla wybranej grupy krajów. Natomiast Tanjuakio i in. (1996) obliczyli mnożniki ekonomiczne dla rolnictwa Delaware, bazując na modelu IMPLAN. Wyniki ich analiz przedstawia ten artykuł. Na podstawie zaprezentowanego przeglądu badań można dojść do wniosku, że brakuje jednomyślności co do dokładnej wartości mnożnika oraz najlepszej metody jego obliczania.

\section{Przegląd badań dotyczących pomiaru mnożnika w rozwoju rolnictwa}

Snodgrass (2014) opracował w postaci tabeli zestawienie 15 badań opublikowanych między 1989 a 2014 rokiem, w których badano rolę mnożnika w rozwoju rolnictwa, obszarów wiejskich, jak i rozwoju krajowym w Afryce Subsaharyjskiej - SSA (ang. SubSaharan Africa). Na podstawie przeglądu tych badań wysunął również kilka wniosków. Zauważył, że mnożnik jest prawdopodobnie niższy w mniejszych, a tym samym bardziej otwartych gospodarkach, niż w gospodarkach większych. Małe gospodarki, w których towary i usługi podlegające wymianie handlowej składają się na dużą część gospodarki (np. Lesotho), odznaczają się niższymi poziomami mnożników niż gospodarki duże, o wysokim udziale towarów i usług rolniczych niepodlegających wymianie handlowej (np. Kamerun, Nigeria i Tanzania). Dostrzegł także, że mnożnik tworzy się głównie poprzez kolejne rundy zwiększonego popytu, ale wpływy po stronie podaży, obejmujące zarówno realokację zasobów i bardziej subtelne efekty nierynkowe, są również ważne.

Od 1980 roku naukowcy zaczęli korzystać z pomysłów występujących w literaturze i na ich podstawie stosować koncepcję mnożnika do badań dotyczących „Zielonej rewolucji” w Azji. Rangarajan (1982) stworzył model sugerujący, że wzrost dochodu rolniczego w Indiach o 1\% przyczyni się do wzrostu w produkcji przemysłowej o $1,5 \%$ oraz do wzrostu całkowitego dochodu narodowego o 1,7\%. Natomiast Hazell i Haggblade (1990) wykorzystali przekrojową analizę ekonometryczną do obliczenia mnożnika w Indiach i okazało się, że średnio w całych Indiach, 100 rupii dodatkowych dochodów z rolnictwa generuje dodatkowe 64 rupie dochodów z działalności pozarolniczej.

Po przeanalizowaniu badań opartych na danych z Azji, Haggblade i in. (1989) wykorzystali model, który Hazell przygotował dla Azji, dla danych z Afryki i obliczyli średnią wartość mnożnika, wynoszącą około 1,5 , tj. nieznacznie mniejszą niż wynikająca ze wcześniejszych ustaleń, odnoszących się do Azji. Przyznali, że ograniczona dostępność danych, dotyczących konsumpcji na obszarach wiejskich, ogranicza zaufanie, co do przeprowadzonych szacunków.

Haggblade i in. (1991) argumentowali, że różnice we wcześniejszych szacunkach mnożnika były wyjaśnione nie tylko przez okoliczności panujące w badanych obszarach, ale także przez modele wykorzystywane do ich szacowania. Zauważyli, że szacowanie odbywające się w oparciu o macierze rachunkowości społecznej zawyża wartość mnożnika o 10-25\%. Dlatego też wprowadzili model, który pozwolił na endogenne dostosowania cen.

Block i Timmer (1994) przeprowadzili badanie, w którym oszacowali mnożniki dla wzrostu dochodów rolniczych i nierolniczych w Kenii. Ich analiza wykazała, że wzrost dochodu w rolnictwie o 1 dolar generuje wzrost dochodu w pozostałej części gospodarki o 0,63 dolara i odwrotnie, wzrost dochodu poza rolnictwem o 1 dolar generuje wzrost 
dochodu w rolnictwie tylko o 0,23 dolara. Ta dysproporcja thumaczy podkreślanie rozwoju rolnictwa w Kenii.

Badanie Delgado i in. (1998) doprowadziło do oszacowania bardzo wysokich wartości mnożnika w krajach, które analizowali. Stwierdzili, że dodanie 1 dolara nowych dochodów rolniczych, potencjalnie zwiększy dochód całkowity w lokalnej gospodarce - poza początkowym 1 dolarem - o dodatkowe 1,88 dolara w Burkina Faso, o 1,48 dolara w Zambii, o 1,24 dolara i o 1,48 dolara w dwóch miejscach w Senegalu oraz o 0,96 dolara w Nigrze.

Dorosh i Haggblade (2003) oszacowali mnożniki dla ośmiu krajów SSA. Badanie przez nich przeprowadzone wskazuje różnice $\mathrm{w}$ wielkości mnożnika, zapewniając wgląd $\mathrm{w}$ oba czynniki: przyczynowe i skutkowe. W małych, otwartych gospodarkach, takich jak Lesotho, zwiększony popyt doprowadził do większego importu netto, zamiast znacznego wzrostu produkcji. Jeżeli towary i usługi niepodlegające wymianie handlowej miały większy udział w strukturze gospodarki (tak jak w Kamerunie, Nigerii i Tanzanii), to wartość mnożnika była większa.

\section{Model Macierzy Rachunkowości Społecznej (SAM)}

Ogólnie rzecz biorąc, macierz rachunkowości społecznej (SAM) to baza danych w formie macierzy, która w sposób ciagły obejmuje wszystkie przepływy pieniężne towarów, usług i dochodów tworzonych pomiędzy wszystkimi czynnikami w gospodarce w okresie referencyjnym (Ferri i Uriel, 2000). SAM odzwierciedla te relacje, a także szersze powiązania, dzięki czemu możliwe jest zbadanie powiązań strukturalnych pomiędzy produkcja, konsumpcja, handlem oraz akumulacją i dystrybucją dochodów. Do najważniejszych cech, które sprawiaja, że SAM nadaje się do badania mnożników, można zaliczyć (Adamson i in., 1999):

- kompleksowość: SAM odzwierciedla łączne przepływy w gospodarce jako całość,

- konsekwentność: SAM jest zgodna z regułą równowagi ogólnej Walrasa; wszystkie rynki są w równowadze,

- transparentność: SAM daje obiektywny obraz strukturalnych stosunków społecznoekonomicznych badanych gospodarek,

- elastyczność: SAM może być wykorzystana jako podstawa do opracowania obliczeniowych modeli równowagi ogólnej (CGE) lub można ją rozszerzyć o dodatkowe moduły, które uważane są za istotne, takie jak dane demograficzne, wskaźniki społeczne i środowiskowe lub oba.

Jednym z modeli społeczno-ekonomicznych, który może być wygenerowany z macierzy rachunkowości społecznej, jest model SAM wykorzystywany do obliczania mnożnika. Model ten to rozwinięcie modelu input-output (przepływów międzygałęziowych), popularnego w literaturze lat 70. i 80. XX wieku. Model SAM służący do obliczania mnożnika jest jednak bardziej kompletny i daje większe wartości niż te uzyskane w modelu input-output (Sadoulet i Janvry, 1995).

Analiza mnożników opiera się na założeniu, że aby wyprodukować więcej w jednym sektorze, niezbędne jest nabycie nakładu od innego. Jest to znane jako wymagania nakładów bezpośrednich. Jednak w celu dostarczenia tych nakładów, różne sektory gospodarki również potrzebują nakładów od innych działalności i tak proces powtarza się, 
tworząc długi łańcuch tak zwanych wymagań nakładów pośrednich. Model SAM wykorzystywany do obliczania mnożnika odzwierciedla całkowite potrzeby po stronie nakładów, zarówno bezpośrednich, jak i pośrednich. Proces ten powoduje również zmiany w wynagrodzeniach czynników, w dochodzie narodowym oraz w jego dystrybucji (Trejos i in., 2004).

Modele SAM służące do obliczania mnożnika są wykorzystywane do określania powiązań między danymi działalnościami - w tym przypadku rolnictwem - i resztą gospodarki. Na przykład, jeśli w produkcji rolnej nastąpi zmiana, to zmieni się także popyt na nakłady, zatrudnienie i generowanie dochodów na obszarach wiejskich. $Z$ drugiej strony, zmiany $\mathrm{w}$ innych sektorach gospodarki, wpływają na produkcję rolną, zatrudnienie w rolnictwie i dystrybucję dochodów gospodarstw rolnych. Im większy mnożnik, tym większy wpływ rolnictwa na gospodarkę (Trejos i in., 2004).

Trejos i in. (2004) przeprowadzili badanie, w którym zastosowali model SAM wykorzystywany do obliczania mnożnika. Modele SAM dla analizowanych krajów zostały podzielony na sześć rachunków, a kapitał, sektory rządowe i zewnętrzne wybrano jako rachunki egzogenne, ułatwiające symulację polityk i szoków zewnętrznych w tym modelu (m.in. zmiany popytu na eksport, zmiany transferów rządowych i wpływów z inwestycji zagranicznych). Model mnożnika pozwala zbadać wpływ różnych egzogenicznych zmian w gospodarce, np. na dochody, dystrybucję wśród gospodarstw domowych, strukturę wydatków instytucjonalnych i przepływ kapitału.

Trejos i in. (2004) obliczone mnożniki umieścili w tabelach, a opis swoich wyników zestawili w trzech następujących kategoriach:

- $\quad$ efekty mnożnikowe w produkcji,

- efekty mnożnikowe przy generowaniu wartości dodanej i dochodów,

- $\quad$ efekty mnożnikowe w przypadku Kostaryki.

Analiza mnożników pod kątem efektów mnożnikowych w produkcji pokazuje, że każda dodatkowa jednostka z pierwotnego sektora wytwarza silny wpływ na inne sektory, generując efekt mnożnikowy w całkowitej produkcji w gospodarce. Efekt ten waha się od 3,076 dodatkowych jednostek w Kanadzie, aż do 5,495 w Argentynie. Jeśli porównamy mnożniki dla rolnictwa $\mathrm{z}$ tymi w innych sektorach gospodarki badanych krajów, widzimy, że mnożniki dla rolnictwa są podobne do tych w innych sektorach. Jest to sprzeczne z przyjętym założeniem, że w rolnictwie występują mniejsze efekty niż w innych sektorach, zwłaszcza przemysłowych (Trejos i in., 2004).

Oszacowano także, że każda dodatkowa jednostka, wyprodukowana w rolnictwie, znacznie zwiększyła produkcję w sektorze spożywczym (od 0,163 w Kanadzie do 0,738 w Argentynie), jak również w sektorze rolniczym (od 0,109 w Kanadzie do 0,566 w Argentynie) (Trejos i in., 2004).

$\mathrm{Na}$ podstawie analizy efektów mnożnikowych występujących przy generowaniu wartości dodanej i dochodów Trejos i in. (2004) wywnioskowali, że każda dodatkowa jednostka podstawowej produkcji rolnej ma bardzo pozytywny wpływ na wynagrodzenia czynników: pracy, kapitału i ziemi (od 1,421 dolara w Kanadzie do 3,347 dolara w Argentynie). Z wyjątkiem Kanady i Brazylii, wynagrodzenie niewykwalifikowanej siły roboczej jest większe w rolnictwie niż w innych sektorach gospodarki, począwszy od 0,587 dolara w Peru do 1,305 dolara w Argentynie.

Każdy dodatkowy dolar popytu na podstawową produkcję rolną generuje wzrost dochodów gospodarstw domowych, począwszy od 1,421 dolara w Kanadzie do 3,347 
dolara w Argentynie. Statystyka ta jest niezwykle ważna, biorąc pod uwage, że rolnictwo generuje więcej dochodów gospodarstw domowych niż inne branże. W przypadku Peru efekt mnożnikowy przemysłu rolnego jest nieco wyższy niż w podstawowym sektorze rolniczym (Trejos i in., 2004).

Analiza mnożników pokazuje również, że każdy dolar z funduszy rządowych, przekazany na dochody gospodarstw domowych, generuje 1,50 dolara, z czego 78 centów w postaci wynagrodzenia kapitału, 4 centy w postaci dzierżawy gruntów i 68 centów w postaci wynagrodzenia za pracę (47 centów za niewykwalifikowanych i 21 centów za wykwalifikowanych pracowników). Branże, które najbardziej korzystają ze zwiększonego popytu różnią się w zależności od kraju. Natomiast do tych, które najbardziej korzystają $\mathrm{z}$ transferów rządowych dochodów dla gospodarstw domowych, zalicza się: handel i sprzedaż (mnożnik 0,41), nieruchomości i czynsze $(0,17)$, usługi administracyjne świadczone przez państwo $(0,16)$ i żywność produkowaną z ryb, warzyw i owoców $(0,15)$ (Trejos i in., 2004).

W przypadku Kostaryki Trejos i in. (2004) przeprowadzili jeszcze bardziej wyczerpującą analizę. Dostępność SAM z bardziej szczegółowymi informacjami na temat instytucji i czynników produkcji pozwoliła zdefiniować rolę rolnictwa w rozwoju gospodarki wiejskiej. W Kostaryce sektory rolne produkcji zielonej kawy, zwierząt gospodarskich, tytoniu, mięsa, mleka, cukru i dojrzałej kawy tworzą mnożniki o wartości większej niż 2, co oznacza, że jeden dolar wzrostu popytu daje więcej niż jeden dodatkowy dolar w innych branżach.

Sektory kawy, cukru, zwierząt gospodarskich i mleka tworzą wysokie wynagrodzenia siły roboczej obszarów wiejskich, podczas gdy tytoń przyczynia się do wyższego wkładu w płace obszarów miejskich. W szczególności, wzrost jednego dolara w produkcji w sektorze zielonej kawy generuje 20 centów z miejskiej pracy, 45 centów z pracy wiejskiej, 4 centy z podatków i 84 centy jako zyski kapitałowe (w tym dzierżawa gruntów) (Trejos i in., 2004).

Podobnie, każdy dodatkowy dolar produkcji zielonej kawy w Kostaryce (na przykład w wyniku zwiększonego popytu na eksport kawy), generuje wzrost dochodów rodziny o 1,18 dolara. Mnożnik ten jest drugim najwyższym i ustępuje tylko mnożnikowi dla sektora usług. Do innych sektorów, które generują wysokie mnożniki dla dochodów rodziny, zalicza się sektory: dojrzałej kawy, nieprzetworzonego tytoniu, zwierząt gospodarskich, bananów i cukru (Trejos i in., 2004).

W przypadku Kostaryki możliwe było również oszacowanie wpływów bezpośredniego transferu funduszy rządowych dla gospodarstw domowych. Każdy dolar przekazany do gospodarstw domowych generował kolejne 99 centów wartości dodanej: 22 centy miejskich wynagrodzeń za pracę, 16 centów wiejskich wynagrodzeń za pracę, 54 centy zysków kapitałowych i 3 centy podatków. Sektorami, które najbardziej skorzystały poprzez zwiększenie swojej produkcji są sektory: chemiczne $(0,24)$, socjalne, społeczności i usług osobistych $(0,22)$, produkcji mięsa i mleka $(0,21)$ i innych produkowanych wyrobów $(0,15)$. Chociaż dodatkowe informacje, dotyczące własności kapitału pomiędzy obszarami wiejskimi i miejskimi były niedostępne, to jednak przedstawiona analiza wskazuje, że bezpośrednie transfery dochodów ze strony rządu dla gospodarstw domowych mogą mieć poważny wpływ na podział dochodów między gospodarstwa domowe wiejskie i miejskie, co daje większe wynagrodzenia w obszarach miejskich i przynosi więcej korzyści dla przemysłu miejskiego oraz rodzin (Trejos i in., 2004). 
Obszerna analiza przeprowadzona dla Kostaryki podkreśla znaczenie zdezagregowanej SAM, która np. jasno określa instytucje, takie jak gospodarstwa domowe wiejskie i miejskie. Na tym etapie konieczne jest przeanalizowanie sektorów w bardziej zdezagregowany sposób, ponieważ niektóre powiązania mogą być zlekceważone lub mnożnik danego sektora może być większy. Ponadto, jak widać w przypadku Kostaryki, konkretne działania, nawet w ramach tego samego sektora, mogą wpływać na równowagę gospodarczą między regionami w bardzo różny sposób. Tak więc, lepsze zrozumienie tego, jak te różnice wpływają na regiony, przyczynia się do lepszego procesu decyzyjnego i lepszej zdolności do oceny wpływu polityki (Trejos i in., 2004).

\section{Model IMPLAN}

Leones i in. (1994) przeprowadzili badania na temat wkładu rolnictwa w gospodarkę państwową. Spośród dwudziestu siedmiu analiz, w trzynastu wykorzystali model inputoutput (przepływów międzygałęziowych). Model IMPLAN został zastosowany dla jedenastu analiz wybranych spośród tych trzynastu. W realizacji tych modeli pojawiają się dwa podstawowe problemy. Jednym $\mathrm{z}$ nich jest zdefiniowanie rolnictwa. W badaniach określenie „rolnictwa” rozciaga się od podstawowej produkcji rolnictwa do bardziej złożonych definicji, które zawierają przemysł rolno-spożywczy, przetwórstwo spożywcze oraz przemysł oparty na zasobach naturalnych. Innym problemem jest to, w jaki sposób wyeliminować lub zminimalizować podwójne liczenie. Johnson i Wade (1994) eliminują pośrednie potrzeby w sektorze rolnym, natomiast Leones i Conklin (1993) odejmuja pośrednie wpływy między sektorami w ramach sektora rolnego. Tanjuakio i in. (1996) w swoim badaniu próbują rozwiązać te dwa problemy poprzez porównanie wkładu gospodarczego dla trzech definicji rolnictwa w Delaware oraz zasugerowanie sposobu zminimalizowania podwójnego liczenia poprzez regulację regionalnych współczynników zakupu $\mathrm{w}$ branżach wchodzących $\mathrm{w}$ skład sektora rolniczego. W swoim artykule zaprezentowali trzy alternatywne definicje rolnictwa. Pierwsza z nich, którą określają jako „Rolnictwo I”, definiuje rolnictwo w tradycyjnym tego słowa znaczeniu, to znaczy jako rolnictwo produkcji. Druga definicja, czyli „Rolnictwo II”, rozszerza tradycyjną definicję poprzez włączenie przemysłu, który dostarcza rolniczych nakładów oraz przemysłu przetwórczego zależnego od lokalnego rolnictwa produkcyjnego. Definicja ta podąża za ogólnym kryterium zaproponowanym przez Leones i Conklina (1993). Trzecia i najszersza definicja, czyli „Rolnictwo III”, obejmuje wszystkie gałęzie przemysłu przetwórstwa żywności i włókienniczego oraz dodatkowo rolnictwo produkcyjne i sektory dostarczające czynniki produkcji.

IMPLAN jest oprogramowaniem opracowanym przez Służbę Leśną USA, wykorzystywanym do analizy input-output (Taylor i in., 1993). Pozwala oszacować regionalne tabele przepływów międzygałęziowych, obliczyć mnożniki i przeprowadzić analizę wpływu przemysłu. Program ten tworzy regionalne tabele przepływów międzygałęziowych przy użyciu krajowych tabel przepływów, które stanowią bazę. Krajowe tabele przepływów międzygałęziowych są tabelami regionalnymi lub przekształconymi w państwowe lub powiatowe przy użyciu szacunkowych regionalnych współczynników zakupu (RPC) (ang. regional purchase coefficients). RPC dla konkretnej branży w danym regionie określa udział popytu regionalnego, który jest dostarczany przez regionalnych producentów (Tanjuakio i in., 1996). 


\section{J. Herda-Kopańska}

W celu uniknięcia podwójnego naliczania, należy wyzerować współczynnik RPC dla branży zawartej w każdej definicji. Bez korekty RPC, podwójne liczenie byłoby spotęgowanym problemem. Eliminowanie podwójnego liczenia $\mathrm{z}$ wartości dodanej i zatrudnienia jest szczególnie ważne, aby zachowały one swoją integralność jako środki wkładu ekonomicznego. Bez korekty RPC, podwójne liczenie w całkowitym poziomie produkcji zostaje przekazane wartości dodanej i zatrudnieniu (Tanjuakio i in., 1996).

IMPLAN może generować dwa zestawy raportów. Pierwszy zestaw dostarcza mnożniki ekonomiczne, które są oparte na odwrotności macierzy Leontiefa. Natomiast drugi zestaw raportów szacuje, wyrażony $\mathrm{w}$ dolarach, wpływ całej gospodarki na egzogeniczne zmiany finalnego popytu w określonych branżach (Tanjuakio $\mathrm{i}$ in., 1996).

IMPLAN generuje dwa zestawy mnożników, tj. mnożniki oparte na produkcji oraz mnożniki typu I i III. Mnożniki oparte na produkcji mierzą, wyrażone $\mathrm{w}$ milionach dolarów, efekty zmiany w finalnym popycie danej branży do regionalnej produkcji brutto, dochodów osobistych, sumy dochodów, wartości dodanej lub zatrudnienia. Natomiast mnożniki typu I i III mierzą, wyrażone $\mathrm{w}$ dolarach, efekty zmiany $\mathrm{w}$ produkcji (lub dochodach osobistych, całkowitych dochodach, wartości dodanej, zatrudnieniu) w danej branży w stosunku do całkowitej produkcji (lub dochodów osobistych, całkowitych dochodów, wartości dodanej, zatrudnienia) w gospodarce lokalnej. Wszystkie zmienne wyrażone są w milionach dolarów, $\mathrm{z}$ wyjątkiem zatrudnienia, które jest przedstawione $\mathrm{w}$ odniesieniu do ilości miejsc pracy (Tanjuakio i in., 1996).

Dla każdej zmiennej wpływu, istnieją cztery rodzaje mnożników: bezpośrednie, pośrednie, indukowane i całkowite. Mnożniki bezpośrednie uwzględniają bezpośredni wpływ na początkową zmianę w produkcji analizowanej branży. Natomiast mnożniki pośrednie uwzględniają zwiększone zakupy nakładów wymaganych przez przemysł produkcyjny dla początkowej zmiany w produkcji. Mnożniki indukowane mierzą efekty zmian $\mathrm{W}$ wydatkach gospodarstw domowych, wynikających ze zmian zatrudnienia, generowanych przez efekty bezpośrednie i pośrednie. W otwartym modelu input-output, takim jak IMPLAN, indukowane efekty szacuje się, przekształcając najpierw bezpośrednie i pośrednie efekty zmian w zatrudnieniu, na podstawie stosunku zatrudnienia do produkcji w każdym sektorze. Zmiana zatrudnienia jest następnie mnożona przez wskaźnik zaludnienia do zatrudnienia w regionie, przekształcając ją na zmianę zaludnienia. Zmiana zaludnienia mnożona jest przez przeciętne regionalne stopy konsumpcji per capita $\mathrm{w}$ sektorach, które oszacowane są na podstawie regionalnej konsumpcji gospodarstw domowych, wygenerowane przez zmiany początkowe finalnego popytu. Ta zmiana w konsumpcji gospodarstw domowych jest traktowana jako dodatkowy zestaw zmian finalnego popytu, które są pomnożone przez odwrotność macierzy Leontiefa, wygenerowaną $\mathrm{w}$ pierwszej rundzie efektów indukowanych. W celu wychwycenia kolejnych rund efektów indukowanych, procedura jest powtarzana aż do zmiany zaludnienia o mniej niż 10 osób (Taylor i in., 1993). Ponieważ sektory usług obejmują znaczną część wydatków gospodarstw domowych, efekty indukowane są w dużej mierze skoncentrowane na wpływach w branżach usługowych. Mnożnik całkowity jest sumą mnożników bezpośrednich, pośrednich i indukowanych (Tanjuakio i in., 1996).

Mnożniki typu I są uzyskiwane przez podzielenie sumy efektów bezpośrednich i pośrednich przez efekty bezpośrednie, będące, wyrażoną w dolarach, zmianą popytu finalnego. Natomiast mnożniki typu III obliczane są poprzez podzielenie sumy efektów bezpośrednich, pośrednich i indukowanych przez efekty bezpośrednie (Tanjuakio i in., 1996). 
Istnieje kilka istotnych zastrzeżeń $\mathrm{w}$ odniesieniu do stosowania analizy input-output. Wskazane jest, aby zdawać sobie sprawę z jej podstawowego założenia, jakim jest stały współczynnik technologii. Technologia ta, inaczej znana jako funkcja produkcji Leontiefa, oferuje ścisłą recepturę produkcji dla każdego sektora i nie pozwala na substytucyjność nakładów. W odniesieniu do stosowania IMPLAN, Tanjuakio i in. (1996) zakładaja również, że regionalne współczynniki zakupu (RPC) odzwierciedlają rzeczywiste warunki popytu i podaży oraz że wydatki gospodarstw domowych są odpowiednio reprezentowane przez współczynniki konsumpcji IMPLAN.

Rezultatem badania przeprowadzonego przez Tanjuakio i in. (1996) są dwa zestawy wyników, odnoszące się do wkładu ekonomicznego rolnictwa. Jednym z nich są mnożniki ekonomiczne przedstawione w tabeli 1 . Zostały one oszacowane dla trzech alternatywnych definicji rolnictwa.

Tabela 1. Mnożniki ekonomiczne dla rolnictwa Delaware

Table 1. Economic Multipliers for Delaware Agriculture

\begin{tabular}{|c|c|c|c|c|c|c|c|}
\hline & & Bezpośrednie & Pośrednie & Indukowane & Całkowite & Typu I & Typu III \\
\hline \multirow[t]{6}{*}{ A. } & Rolnictwo I & & & & & & \\
\hline & Produkcja & 1,0000 & 0,2120 & 0,4423 & 1,6543 & 1,2120 & 1,6543 \\
\hline & Dochód osobisty & 0,1069 & 0,0494 & 0,1540 & 0,3103 & 1,4623 & 2,9028 \\
\hline & Dochód całkowity & 0,4053 & 0,1031 & 0,2320 & 0,7404 & 1,2544 & 1,8268 \\
\hline & Wartość dodana & 0,4121 & 0,1256 & 0,2622 & 0,7999 & 1,3048 & 1,9409 \\
\hline & Zatrudnienie & 9,7366 & 1,5959 & 5,8742 & 17,2067 & 1,1640 & 1,7675 \\
\hline \multirow[t]{6}{*}{ B. } & Rolnictwo II & & & & & & \\
\hline & Produkcja & 1,0000 & 0,2212 & 0,3235 & 1,5447 & 1,2212 & 1,5447 \\
\hline & Dochód osobisty & 0,1602 & 0,0575 & 0,1130 & 0,3306 & 1,3588 & 2,0644 \\
\hline & Dochód całkowity & 0,3195 & 0,1066 & 0,1701 & 0,5962 & 1,3336 & 1,8659 \\
\hline & Wartość dodana & 0,3232 & 0,1221 & 0,1923 & 0,6376 & 1,3777 & 1,9727 \\
\hline & Zatrudnienie & 8,1723 & 1,9140 & 5,0692 & 15,1555 & 1,2342 & 1,8545 \\
\hline \multirow[t]{6}{*}{ C. } & Rolnictwo III & & & & & & \\
\hline & Produkcja & 1,0000 & 0,2208 & 0,2933 & 1,5141 & 1,2208 & 1,5141 \\
\hline & Dochód osobisty & 0,1533 & 0,0593 & 0,1031 & 0,3157 & 1,3870 & 2,0597 \\
\hline & Dochód całkowity & 0,3003 & 0,1067 & 0,1550 & 0,5620 & 1,3553 & 1,8716 \\
\hline & Wartość dodana & 0,3037 & 0,1214 & 0,1753 & 0,6004 & 1,3996 & 1,9769 \\
\hline & Zatrudnienie & 7,2590 & 1,9127 & 4,5878 & 13,7596 & 1,2635 & 1,8955 \\
\hline
\end{tabular}

Źródło: Tanjuakio i in. (1996).

Mnożniki całkowite wartości dodanej wyniosły 0,80, 0,64 i 0,60 dla każdego dolara produkcji odpowiednio dla Rolnictwa I, II, i III. Używając Rolnictwa II jako przykładu, mnożnik równy 0,64 oznacza, że dla każdego dolara produkcji wytworzonej przez Rolnictwo II, całkowita wartość dodana generowana dla gospodarki Delaware wynosi 0,64 dolara. Składa się ona z 0,32 dolara pochodzące bezpośrednio z Rolnictwa II (mnożnik bezpośredni), 0,12 dolara z przemysłu dostarczającego nakładów na Rolnictwo II (mnożnik pośredni) i 0,19 dolara $\mathrm{z}$ innych branż, będące wynikiem dochodów wygenerowanych w 
Rolnictwie II i nakładów dostawców (mnożnik indukowany). Przechodząc z jednej definicji rolnictwa do następnej, mnożniki zmniejszały się, zwiększając liczbę zagregowanych branż. Należałoby oczekiwać, że wartość dodana, przypadająca na dolara produkcji w zagregowanym sektorze rolniczym, zmniejsza się, zwiększając liczbę zawartych branż przetwórstwa, ponieważ przemysł przetwórczy ma na ogół niższą wartość dodaną wkładów, przypadającą na dolara produkcji. Co więcej, liczba branż z regionalnymi współczynnikami zakupu wynoszącymi zero zwiększa się wraz z poszerzaniem definicji rolnictwa o kolejne gałęzie przemysłu przetwórczego (Tanjuakio i in., 1996).

Mnożniki typu I wartości dodanej, które są coraz bardziej powszechne w analizach input-output, wahały się w przedziale od 1,30 do 1,40. Ponownie używając Rolnictwa II jako przykładu, mnożnik równy 1,38 oznacza, że dla każdego dolara wartości dodanej całkowitej produkcji Rolnictwa II, wartość dodana wygenerowana dla gospodarki Delaware, wynikająca z produkcji Rolnictwa II i wymaganych nakładów wynosi 1,38 dolara. Mnożniki typu III wartości dodanej były, zgodnie z oczekiwaniami, znacznie wyższe, począwszy od 1,94 dla Rolnictwa I do 1,98 dla Rolnictwa III. Dla Rolnictwa II mnożnik oznacza, że wkład całkowitej wartości dodanej Rolnictwa II dla każdego dolara własnej wartości dodanej wynosi 1,97 dolara. Mnożniki typu III obejmuja, oprócz efektów bezpośrednich i pośrednich, efekty wydatków konsumpcyjnych $\mathrm{z}$ dochodów wygenerowanych przez wszystkie bezpośrednie i pośrednie działalności produkcyjne. Pod względem wpływu na zatrudnienie, Rolnictwo I generowało siedemnaście miejsc pracy na milion dolarów produkcji w 1991 r. Dla Rolnictwa II i III było to odpowiednio piętnaście i czternaście miejsc pracy. Mnożniki typu I i typu III zatrudnienia były stosunkowo mniejsze, ale miały taką samą tendencję wzrostową, jak te same typy mnożników dla wartości dodanej (Tanjuakio i in., 1996).

\section{Podsumowanie}

Próby przeanalizowania wielkości mnożnika w rozwoju rolnictwa zaczęły się w $1980 \mathrm{r}$. Od tego czasu przeprowadzono wiele badań w tym kierunku. Na ich podstawie można wywnioskować, że poziom mnożnika jest niższy w mniejszych i bardziej otwartych gospodarkach niż w gospodarkach większych i zamkniętych. Warto również zauważyć, że wśród badaczy nie ma zgodnego stanowiska w kwestii wartości mnożnika.

Do badania mnożników w rozwoju rolnictwa można wykorzystać macierz rachunkowości społecznej (SAM). Analiza mnożników za pomocą SAM umożliwia generowanie symulacji, które zapewniają kryteria identyfikacji kluczowych sektorów gospodarki. Określają one nie tylko te większe powiązania produkcyjne, ale również te, które generują większą wartość dodaną i mają korzystniejszy wpływ na podział dochodów między gospodarstwa wiejskie i miejskie (Trejos i in., 2004).

Do analizy mnożników w rolnictwie można również zastosować modele input-output (przepływów międzygałęziowych), do których zalicza się model IMPLAN. Na podstawie tego modelu Tanjuakio i in. (1996) przeprowadzili badanie, z którego wynika, że mnożniki całkowite wartości dodanej mieściły się $\mathrm{w}$ przedziale od 0,60 do 0,80 . Wraz $\mathrm{z}$ poszerzaniem definicji rolnictwa o kolejne gałęzie przemysłu przetwórczego, wartość mnożników była coraz mniejsza, natomiast liczba zagregowanych branż rosła. Przyczyną tego może być to, że przemysł przetwórczy ma zazwyczaj niższą wartość dodaną wkładów, jaka przypada na dolara produkcji. Odwrotną tendencję można zaobserwować w przypadku 
mnożników typu I oraz typu III wartości dodanej. Wraz z poszerzaniem definicji rolnictwa o kolejne gałęzie przemysłu przetwórczego, wartości tych mnożników rosły. Mnożniki typu I wartości dodanej mieściły się w przedziale od 1,30 do 1,40 , natomiast mnożniki typu III wartości dodanej były znacznie wyższe i obejmowały zakres od 1,94 do 1,98. Jeżeli chodzi o mnożniki typu I i typu III zatrudnienia, to były one stosunkowo mniejsze, ale miały również tendencję wzrostową.

\section{Literatura}

Adamson, M., Montiel, N., Alarcón, J., Vargas, H., Solano, A., Sandoval, F. (1999). Matrices de contabilidad social: nota metodológica y una propuesta para Costa Rica. San José, Costa Rica: IICE-Universidad de Costa Rica.

Block, S., Timmer, P. (1994). Agriculture and Economic Growth: Conceptual Issues and the Kenyan Experience. Development Discussion Paper, No. 498.

Delgado, C.L., Hopkins, J., Kelly, V. (1998). Agricultural Linkages in Sub-Saharan Africa. International Food Policy Research Institute, Research Report 107.

Dorosh, P., Haggblade, S. (2003). Growth linkages, Price Effects and Income Distribution in Sub-Saharan Africa. Journal of African Economies, 12(2), 207-235.

Ferri, J., Uriel, E. (2000). Multiplicadores contables y análisis estructural en la matriz de contabilidad social: una aplicación al caso español. Investigaciones Económicas, 24, 419-453.

Haggblade, S., Hammer, J., Hazell P. (1991). Modeling Agricultural Growth Multipliers. American Journal of Agricultural Economics, 73(2), 361-374.

Haggblade, S., Hazell, P., Brown, J. (1989). Farm-Nonfarm Linkages in Rural Sub-Saharan Africa. World Development, 17(8), 1173-1201.

Hazell, P., Haggblade, S. (1990). Rural-urban Growth Linkages in India. Working Paper, No. 430, Washington: World Bank.

Johnson, T.G., Wade, E.W. (1994). The Economic Impact of the Agriculture Sector in Virginia. Department of Agricultural and Applied Economics, Virginia Polytechnic Institute and State University.

Leones, J.P., Conklin, N.C. (1993). Agriculture in the Arizona Economy. Arizona Department of Agriculture, Arizona State University and The University of Arizona.

Leones, J.P., Schulter, G., Goldman G. (1994). Redefining Agriculture in Interindustry Analysis. American Agricultural Economics Association, 76, 1123-1129.

Rangarajan, C. (1982). Agricultural Growth and Industrial Performance in India. Research Report, No. 33, Washington: IFPRI.

Sadoulet, E., de Janvry, A. (1995). Quantitative development policy analysis. Baltimore, Maryland: John Hopkins University Press.

Snodgrass, D. (2014). Agricultural transformation in sub-Saharan Africa and the Role of the Multiplier: A Literature Review. USAID LEO, Report No. 4.

Tanjuakio, R.V., Hastings, S.E., Tytus, P.J. (1996). The Economic Contribution of Agriculture in Delaware. Agricultural and Resource Economics Review, 25, 46-53.

Taylor, C., Winter, S., Alward, G., Siverts E. (1993). Micro IMPLAN User's Guide, Version 91-F. U.S. Department of Agriculture, Forest Service.

Trejos, R., Arias, J., Segura, O., Vargas, E. (2004). More than Food on the Table: Agriculture's True Contribution to the Economy. Interagency Group on Rural Development. Pobrane 11 grudnia 2015 z: http://repiica.iica.int/docs/B0751i/b0751i.pdf.

Do cytowania / For citation:

Herda-Kopańska J. (2018). Pomiar mnożnika w rozwoju rolnictwa. Problemy Rolnictwa Światowego, 18(1), 48-57; DOI: 10.22630/PRS.2018.18.1.4

Herda-Kopańska J. (2018). Measurement of the Multiplier in the Development of Agriculture (in Polish). Problems of World Agriculture, 18(1), 48-57; DOI: 10.22630/PRS.2018.18.1.4 